
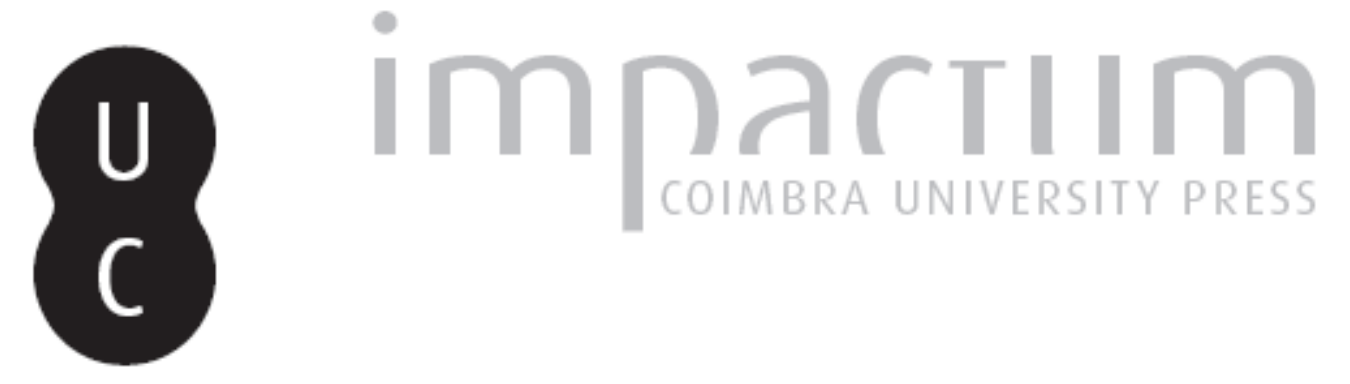

\title{
Quod non est in actis, non est in mundo: mecanismos de disciplina interna e externa no Auditório Eclesiástico de Coimbra
}

Autor(es): Gouveia, Jaime Ricardo

Publicado por: Centro de História da Sociedade e da Cultura

URL

persistente:

URI:http://hdl.handle.net/10316.2/39582

DOI:

DOI:http://dx.doi.org/10.14195/1645-2259_9_7

Accessed : $\quad$ 26-Apr-2023 05:36:10

A navegação consulta e descarregamento dos títulos inseridos nas Bibliotecas Digitais UC Digitalis, UC Pombalina e UC Impactum, pressupõem a aceitação plena e sem reservas dos Termos e Condições de Uso destas Bibliotecas Digitais, disponíveis em https://digitalis.uc.pt/pt-pt/termos.

Conforme exposto nos referidos Termos e Condições de Uso, o descarregamento de títulos de acesso restrito requer uma licença válida de autorização devendo o utilizador aceder ao(s) documento(s) a partir de um endereço de IP da instituição detentora da supramencionada licença.

Ao utilizador é apenas permitido o descarregamento para uso pessoal, pelo que o emprego do(s) título(s) descarregado(s) para outro fim, designadamente comercial, carece de autorização do respetivo autor ou editor da obra.

Na medida em que todas as obras da UC Digitalis se encontram protegidas pelo Código do Direito de Autor e Direitos Conexos e demais legislação aplicável, toda a cópia, parcial ou total, deste documento, nos casos em que é legalmente admitida, deverá conter ou fazer-se acompanhar por este aviso.

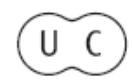



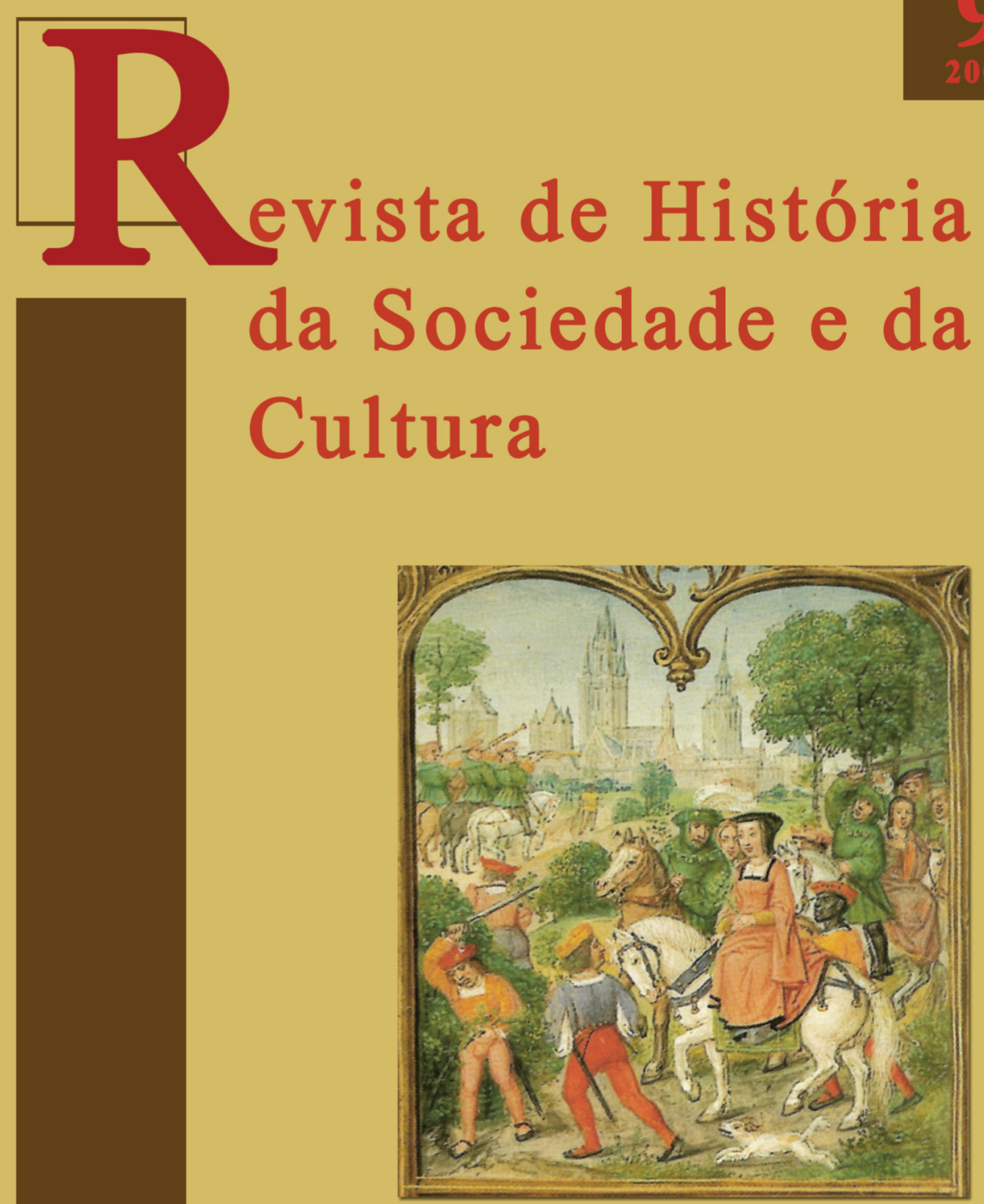

Centro de História da Sociedade e da Cultura Universidade de Coimbra

Coimbra 


\title{
Quod non est in actis, non est in mundo: mecanismos de disciplina interna e externa no Auditório Eclesiástico de Coimbra*
}

\author{
Jaime Ricardo Gouveia \\ Bolseiro do Ministério dos Negócios Estrangeiros Português e da \\ Fundação para a Ciência e Tecnologia \\ Instituto Universitário Europeu - Florença \\ jaime.teixeira@eui.eu
}

Texto entregue em/Text submited on: 19/02/2009

\section{Resumo/Abstract:}

Pretende-se com este estudo analisar um dos dispositivos de vigilância e disciplinamento social existentes no mundo moderno, praticamente inexplorado até à data: os tribunais eclesiásticos, vulgarmente designados por Auditórios. Focado concretamente no de Coimbra, este artigo procura, em primeiro lugar, avaliar a produção historiográfica neste domínio. De seguida, apurar algumas dinâmicas internas deste tribunal, com o fito de explicitar o seu modo de funcionamento. Finalmente, abordar detalhadamente um dos mecanismos destinados a expurgar o Juízo Eclesiástico de actos de corrupção e ilegalidade, as devassas, nomeadamente aquela que foi ordenada, em 1741, por D. Miguel da Anunciação.

This paper envisages the analysis of a tool of social monitoring and discipline of the modern world, virtually disregarded until now: the ecclesiastical courts, commonly called Auditorio. Essentially focusing on the ecclesiastical court of Coimbra, this paper seeks primarily to assess historiographic developments in this area. This is followed by an assessment of the internal dynamics of this court, in view of understanding its modus operandi. Finally, it scrutinises one of the mechanisms used to purge the ecclesiastical justice of all corruptive and illegal behaviour, the devassas (investigation), namely the one commisssioned in 1741 by D. Miguel da Anunciação.

Palavras chave/Key words:

História da Igreja; Diocese de Coimbra; Justiça Eclesiástica; Auditório Eclesiástico; D. Miguel da Anunciação.

Church history; Diocese of Coimbra; Ecclesiastical justice; Ecclesiastical court; D. Miguel da Anunciação.

* A versão final deste estudo beneficiou dos comentários, sugestões e críticas efectuadas pelos Professores José Pedro Paiva; Francisco Bethencourt e Bartolomé Yun Casalilla, a quem agradeço. 


\section{Os tribunais eclesiásticos enquanto dispositivos de vigilância e disciplinamento social: balanço historiográfico}

Os trabalhos que nas últimas décadas se foram produzindo no âmbito da História Religiosa, renovaram-na em profundidade, nomeadamente no que diz respeito a algumas categorias e perspectivas de análise que abundantemente têm sido discutidas à escala europeia. Novas abordagens se delinearam, tendo-se verificado um paulatino interesse na passagem da História da Igreja para a História Religiosa. Logo a partir dos anos 70 do século XX, estudos de Keith Thomas e Jean Delumeau delinearam um novo programa de investigação neste campo, em que o objectivo da História da Reforma passava a ser a análise do carácter e diversidade regional das crenças e práticas cristãs e o exame de como essas grandes mudanças em marcha alteraram a experiência, afiliação e identidade religiosa, dos vários estratos sociais da Europa ${ }^{1}$. Outra das inovações foi o aparecimento posterior de alguns estudos comparativos sobre várias tradições confessionais ${ }^{2}$. Mudança fundamental foi também aquela que se verificou com o desenvolvimento do conceito de disciplinamento social. A primeira alusão que se lhe conhece (sozialdisciplinierung) encontra-se nos estudos de Gerhard Oestreich, em torno do neo-estoicismo de Justus Lipsius e da sua influência no processo de construção do chamado "Estado Absolutista" a proposta restringiu-se ao campo da História Política. Na década de 1980, dois alemães, Wolfgang Reinhard e Heinz Schilling, aplicaram-no à História Religiosa, pretendendo estudar os vínculos estreitos entre o poder político e as instituições e agentes do poder eclesiástico e religioso. Elaboraram, assim, o conceito de confessionalização (Konfessionalisierung) propondo-o como paradigma de interpretação de uma História Religiosa da Época Moderna que, face a uma visão equacionada em termos estritamente eclesiásticos,

1 THOMAS, Keith - Religion and the Decline of Magic: Studies in popular beliefs in sixteenth and seventeenth century England. Harmondsworth: Penguin Books, 1973; DELUMEAU, Jean - Le Catholicisme entre Luther et Voltaire. Paris: Presses Universitaires de France, 1979.

2 BENEDICT, Philip - What is Post-Confessional Reformation History. Archive for Reformation History. 97 (2006) 277-283.

3 Veja-se a última edição em Inglês: OESTREICH, Gerhard - Neostoicism and the Early Modern State. Cambridge: Cambridge University Press, 2008. 
colocaria a análise dos processos e fenómenos de carácter religioso numa perspectiva relacional, ou seja, atenta aos contextos político, social e cultural nos quais esses fenómenos se inscreviam. Schilling, a título de exemplo, defende que é errado usar o termo Época da Contra-Reforma. Este, a seu modo de ver, deve ser preterido por Época da Confessionalização ou Idade Confessional (entre 1540 e 1620), pela dinâmica revolucionária do período e implicações político-sociais da mutação eclesiástico-religiosa ${ }^{4}$.

Estas perspectivas de interpretação fornecidas pela aplicação dos conceitos de confessionalização e de disciplinamento social têm favorecido o desenvolvimento de um número crescente de estudos no âmbito da história religiosa dos séculos XVI a XVIII ${ }^{5}$. Destaque, neste contexto, para o livro publicado em 2004, coordenado por Herman Roodenburg e Pieter Spierenburg, dedicado ao controlo social na Europa no período compreendido entre 1500 e 1800, contendo vários artigos onde estes conceitos são amplamente discutidos e usados ${ }^{6}$.

Todavia, frise-se também, que o quadro de interpretação que decorre destas duas categorias (confessionalização e disciplinamento) não deixou de suscitar interpretações díspares, dúvidas e controvérsias, nomeadamente no que concerne à eficácia dos dispositivos e dos agentes envolvidos em tais processos, bem como à aplicação de um modelo que terá aplicabilidade em algumas regiões da Europa Central e do Norte, mas que é susceptível de

4 REINHARD, Wolfgang - Pressures towards Confessionalization? Prolegomena to a Theory of the Confessional Age. The German Reformation: The Essential Readings (edited by C. Scott Dixon). London: Blackwell, 1999, p.169-192; SCHILLING, Heinz - Religion, Political Culture and the Emergency of Early Modern State. Essays in German and Dutch History. Leiden, New York, Koln: E. J. Brill, 1992.

5 EURICH, S. Amanda - Religious Toleration and Confessional Identity: Catholics and Protestants in Seventeenth-Century Orange. Archive for Reformation History. 97 (2006) 249-275; PAIVA, José Pedro de Matos - Inquisição e Visitas Pastorais. Dois mecanismos complementares de controlo social? Revista de História e Teoria das Ideias. 11 (1989) 85-102; PALOMO, Federico - A Contra-Reforma em Portugal (1540-1700). Lisboa: Livros Horizonte, 2006; PALOMO, Federico - Fazer dos campos escolas excelentes. Os jesuitas de Évora e as missões do interior em Portugal (1551-1630). Lisboa: Fundação Calouste Gulbenkian; Fundação para a Ciência e Tecnologia, 2003.

6 ROODENBURG, Herman; SPIERENBURG, Pieter (co-editors) - Social Control in Europe, 1500-1800. Vol.1. Ohio: State University Press, 2004. 
falhar se perspectivado noutros espaços europeus ${ }^{7}$. Além da insistência na proximidade e semelhança dos processos vividos nos territórios protestantes e católicos, como fez Headley, convém não descurar também os factores de diferenciação ${ }^{8}$. Parece, assim, conveniente, entre outros procedimentos metodológicos, entrar em linha de conta com o factor "escala de análise" e procurar perceber como processos impulsionados a partir do topo das hierarquias sociais e políticas foram objecto de adaptações e negociações em função das realidades que encontraram na sua realização prática ${ }^{9}$. Será assim, no caso português, importante perceber quais os dispositivos quer desse ímpeto confessionalizador, quer da vigilância e disciplinamento social que se exerceu sobre a cristandade ${ }^{10}$.

De resto, no tocante a Portugal, esta questão do disciplinamento social não tem sido acolhida pela historiografia como campo de eleição. Por conseguinte, nos últimos trinta anos tem-se vindo a consagrar uma maior atenção ao estudo da Inquisição, preterindo-se outras instituições religiosas que, como o Santo Ofício tiveram um peso, uma presença e uma capacidade de

7 BENEDICT, Philip - What is Post-Confessional Reformation History? Archiv für Reformationsgeschichte. 97 (2006) 278-84; BENEDICT, Philip - Confessionalization in France? Critical reflections and new evidence in MENTZER, Raymond A. e SPICER, Andrew (ed.) - Society and Culture in the Hugenot World, 1559-1685. Cambridge: Cambridge University Press, 2001, p. 44-61; HANLON, Gregory - Confession and Community in Seventeenth-Century France: Catholic and Protestant Coexistence in Aquitaine, Philadelphia: University of Pennsylvania Press, 1993; FARR, James - Confessionalization and Social Discipline in France, 1530-1685. ARG. 94 (2003) 276-293; HEAD, Randolph C - Catholics and Protestants in Graubunden: Confessional Discipline and Confessional Identities without an Early Modern State. German History. 17 (1999) 321-345; HENDRIX, Scott - PostConfessional Research and Confessional Commitement. Archive for Reformation History. 97 (2006) 284-287; PAIVA, José Pedro - El Estado en la Iglesia y la Iglesia en el Estado. Contaminaciones, dependencias y dissidencia entre la monarquia y la Iglesia del reino de Portugal (1495-1640). Manuscrits. 25 (2007) 45-57; ROPER, Lyndal - Allegiance and Reformation History. Archive for Reformation History. 97 (2006) 289-297; SHAGAN, Ethan F. - Can Historians End the Reformation? Archive for Reformation History. 97 (2006) 298-306.

8 HEADLEY, John; HILLERBRAND, J.; PAPALAS, Anthony J. - Confessionalization in Europe, 1555-1700. Essays in honour and memory of Bodo Nischam. Burlington: Ashgate, 2004, p.17-25; PAIVA, José Pedro - El Estado..., cit., p. 45-57.

9 PALOMO, Federico - A Contra-Reforma ..., cit., p. 13-14.

${ }^{10}$ BROGGIO, Paolo - Le missioni dei gesuiti nel mondo ispanico in età moderna. La circolazione delle strategie di evangelizzazione tra Europa e Nuovi Mondi (Spagna, Perù, Cile - 1581-1705). Florença: Instituto Universitário Europeu, 2003. 
acção muito significativas no seio da sociedade. Além da Inquisição, bispos e ordens religiosas foram outros pólos fundamentais na organização do campo religioso moderno ${ }^{11}$. Muito embora se revele importante estudar isoladamente cada um deles, é necessário também que se proceda a investigações cujo problema teórico se debruce sobre a sua actuação conjunta, e estudos comparativos não apenas entre o reino português e o espaço colonial como abordagens mais vastas numa escala ibérica e atlântica ${ }^{12}$.

Além do Santo Ofício, as visitas pastorais efectuadas pelos bispos foram já também objecto de importantes estudos sobre as transgressões das populações no domínio da moral e da vigilância e disciplinamento das populações, muito embora haja ainda muito a fazer neste campo ${ }^{13}$. Finalmente, outro dos dispositivos de vigilância e disciplinamento social que actuou no dirimir das imbricações entre o sagrado e o profano, sobre o qual a historiografia continua parca, foram os tribunais eclesiásticos. Sobre eles nenhum estudo de monta existe em Portugal, muito em parte devido ao facto dos fundos documentais dos auditórios eclesiásticos se terem perdido praticamente na sua totalidade, nomeadamente os processos. Aquela que foi a única grande obra consagrada ao estudo da Igreja em Portugal durante muitos anos, da autoria de Fortunato de Almeida, não se debruçou sobre o funcionamento das estruturas do governo episcopal, nem mencionou,

${ }^{11}$ PAOLOMO, Federico - A Contra-Reforma ..., cit., p. 30-31.

${ }^{12}$ Existem, todavia, alguns estudos que marcaram já este campo de análise. Citam-se apenas alguns: BETHENCOURT, Francisco-A Igreja in BETHENCOURT, Francisco; CHAUDHURI, Kirti (ed.) - História da Expansão Portuguesa. Lisboa: Temas e Debates, 1988, vol. 2, p. 369-386; BOSHI, Caio - Estruturas Eclesiásticas e Inquisição in BETHENCOURT, Francisco; CHAUDHURI, Kirti (ed.) - História ..., cit., vol. 2, p. 429-453; BOSHI, Caio - Episcopado e Inquisição in BETHENCOURT, Francisco; CHAUDHURI, Kirti (ed.) - História ..., cit., vol. 3, p. 332-395; FEITLER, Bruno - Nas malhas da consciência. Igreja e Inquisição no Brasil. Nordeste, 1640-1750. São Paulo: Alameda, Poebus, 2007; MARCOCCI, Giuseppe Inquisição, Jesuítas e Cristãos-Novos em Portugal no século XVI. Revista de História e Teoria das Ideias. 25 (2004) 247-326; PAIVA, José Pedro - Os bispos de Portugal e do império (1495-1777). Coimbra: Imprensa da Universidade, 2006; PAIVA, José Pedro - Os dominicanos e a Inquisição em Portugal (1536-1614). Noroeste - Revista de História. I (2005) 167-229; PAIVA, José Pedro - Os bispos e a Inquisição Portuguesa (1536-1613). Lusitania Sacra. $2^{\mathrm{a}}$ série. XV (2003) 43-76; PAIVA, José Pedro - Inquisição e Visitas Pastorais..., cit..

${ }^{13}$ Para uma visão de síntese actualizada ver PAIVA, José Pedro - As Visitas Pastorais in AZEVEDO, Carlos Moreira (dir.) - História Religiosa de Portugal. Lisboa: Círculo de Leitores, 2000, vol. II, p. 250-255. 
sequer, a existência dos vários tribunais diocesanos ${ }^{14}$. A História Religiosa de Portugal, sob a direcção de Carlos Moreira de Azevedo, contém apenas uma síntese da autoria de José Pedro Paiva, num capítulo dedicado às dioceses e organização eclesiástica que traça uma importante visão de como funcionavam a burocracia e os aparelhos da administração diocesana, resumindo aqui algumas das ideias que figuraram num artigo do mesmo autor publicado na revista Lusitania Sacra, em 1991, o qual elegeu como espaço de análise a diocese de Coimbra ${ }^{15}$. António Manuel Hespanha, num trabalho sobre as instituições do Antigo Regime, traça uma importante perspectiva de síntese sobre a jurisdição eclesiástica, com a revelação de aspectos fundamentais para se perceber a dinâmica interna dos tribunais eclesiásticos ${ }^{16}$. A única monografia especialmente dedicada à análise de um Auditório Eclesiástico apareceu em 2003, da autoria de Ana Cristina Trindade e Dulce Teixeira. No entanto, as autoras centram-se apenas no Regimento do Auditório do Funchal e num número escasso de processos existentes no espólio documental daquele tribunal eclesiástico, bem como em alguns outros documentos pertencentes ao seu cartório ${ }^{17}$.

Acrescem a estes estudos o recente artigo da autoria de João Rocha Nunes, onde se analisa a actividade do Auditório Eclesiástico de Viseu no período compreendido entre 1684 e 1689, portanto durante o governo de D. Ricardo Russel, através de um livro da Câmara Eclesiástica com o registo de sumários das sentenças aplicadas nesse mesmo período. Trata-se de uma análise monográfica pioneira que permite entender algumas das principais linhas de actuação deste importante órgão eclesiástico ${ }^{18}$.

${ }^{14}$ ALMEIDA, Fortunato de - História da Igreja em Portugal. Barcelos: Livraria Civilização Editora, 1986, 5 vol. (1ª edição entre 1910-1928).

${ }^{15}$ PAIVA, José Pedro - A administração diocesana e a presença da Igreja. O caso da diocese de Coimbra nos séculos XVII e XVIII. Lusitania Sacra. 2a série, III (1991) 71-110; PAIVA, José Pedro - Dioceses e organização eclesiástica in AZEVEDO, Carlos Moreira (dir.) - História ..., cit., vol. II, p.187-199.

${ }^{16}$ HESPANHA, António Manuel - Poder e Instituições no Antigo Regime. Lisboa: Edições Cosmos, 1992, p. 43-44; 56-57.

${ }^{17}$ TRINDADE, Ana Cristina M.; TEIXEIRA, Dulce Manuela Maia R. - O Auditório Eclesiástico da Diocese do Funchal. Regimento e espólio documental do século XVII. Funchal: Instituto Superior de Administração e Línguas, 2003.

${ }^{18}$ NUNES, João Rocha - Crime e castigo: pecados públicos e disciplinamento social na Diocese de Viseu (1684-1689). Revista de História da Sociedade e da Cultura. 6 (2006) 177-213. 
Poder-se-á concluir, assim, que há ainda um longo caminho a percorrer no que respeita ao estudo e conhecimento do funcionamento deste dispositivo de justiça com decisivas implicações no âmbito do disciplinamento social.

\section{O Auditório Eclesiástico de Coimbra}

A Igreja dispunha de autonomia de governo e de regulamentação (autonomia jurisdicional). Possuía um direito próprio - o direito canónico, autonomia dogmática, de governo e disciplinar ${ }^{19}$. A administração eclesiástica das dioceses era exercida pelos prelados e por um conjunto de agentes enquadrados em aparelhos burocrático-administrativos que, de acordo com José Pedro Paiva, se foram estruturando e complexificando ao longo do tempo, enquanto que a circulação de bispos e oficiais que serviam no governo episcopal e ainda o aparecimento gradual de uma cultura organizacional própria, foram estabelecendo uma relativa uniformidade no desenrolar quotidiano dos negócios dos bispados. Ainda segundo o mesmo autor, as estruturas diocesanas de governo eram eficientes e das que melhor estavam articuladas, mesmo se comparadas com os grandes poderes institucionais do tempo, de que são exemplo os órgãos do Estado e a Inquisição ${ }^{20}$.

A administração episcopal, exercida à cabeça pelo bispo, provisor e vigário-geral, acolitados por um conjunto significativo de outros agentes judiciais, estruturava-se em torno de dois aparelhos que actuavam de forma complementar e coordenada. Por um lado, a Câmara Eclesiástica, ou Mesa Episcopal, por outro, o Auditório Eclesiástico ${ }^{21}$.

O Auditório era um dos pilares do poder judicial diocesano. O bispado estava inscrito numa província eclesiástica que reunia várias dioceses, configurando-se, por esta razão, um universo onde existiam as sés metropolitanas ou arquiepiscopais, e as suas sufragâneas ou episcopais. No quadro da hierarquia eclesiástica judicial, os auditórios eram apenas tribunais ordinários de primeira instância, existindo naturalmente outros juízos religiosos para

\footnotetext{
${ }^{19}$ HESPANHA, António Manuel - Poder e Instituições ..., cit., p. 43-44 e 56-57.

${ }^{20}$ PAIVA, José Pedro - Dioceses..., cit., p. 187-199.

${ }^{21}$ PAIVA, José Pedro - A administração..., cit., p. 71-110.
} 
os quais era possível apelar, os chamados tribunais de segunda, terceira e última instâncias. Apelar de determinada decisão tomada pelos tribunais religiosos para o juízo secular, isto é, para os tribunais régios, era também possível, sobretudo para o Tribunal da Relação.

O Auditório tinha múltiplas competências, não apenas de cariz estritamente religioso como também sobre leigos em matéria de conduta moral, julgando de acordo com as constituições diocesanas e os códigos de Direito Canónico. Por conseguinte, havia assim situações que, em termos de jurisdição, eram do foro misto (causae mixti fori), não julgadas exclusivamente por um Tribunal, nomeadamente aquelas que eram portadoras de elementos temporais e espirituais ${ }^{22}$. O poder judicial que o bispo possuía não contemplava, em regra, o clero regular, corpo eclesiástico que detinha mecanismos judiciais próprios cuja judicatura era exercida em primeira instância pelo superior de determinado cenóbio, e em segunda instância pelo provincial da respectiva religião ${ }^{23}$.

Como qualquer tribunal, o Auditório Eclesiástico era um órgão colegial, composto por vários ministros. Através do Regimento do de Coimbra, verifica-se que o perfil, competências e número dos seus oficiais subsistiu de forma relativamente constante, uma vez que esse código normativo foi reimpresso no século XVIII sem alterações. O Auditório conimbricense tinha à cabeça o bispo, acolitado por dois oficiais de relevo que, juntamente consigo, ocupavam a cúspide do tribunal: o provisor e o vigário-geral. Existiam depois um promotor, vários advogados (também designados procuradores), vários escrivães e notários apostólicos, um meirinho, alguns

${ }^{22}$ HESPANHA, António Manuel - Poder e Instituições..., cit., p. 43-44 e 56-57; SILVA, José António Gomes da - Tribunais Eclesiásticos in AZEVEDO, Carlos Moreira (dir.) - Dicionário de História Religiosa de Portugal. Lisboa: Círculo de Leitores e Cento de Estudos de História Religiosa, vol. 4, 2001, p. 303-305; Enciclopedia de la Religion Católica. Barcelona: Dalmau y Jover, S A., 1956, tomo VII, p. 352; New Catholic Encyclopedia (Dir. by Tha to Zwi). New York, St. Louis, San Francisco, Toronto, London, Sydney: Catholic University of America, [s. n.], vol. XIV, p.284-287. Sobre uma perspectiva histórica dos vários tribunais eclesiásticos veja-se ainda Enciclopedia Cattolica. Firenze: Casa Editrice G. C. Sansoni, vol.XII, 1954, p. 495-510. Sobre alguns casos concretos de apelação para tribunais de segunda instância veja-se FERREIRA, Maria Georgina - Catálogo do Cartório do Colégio de Nossa Senhora da Graça. Boletim do Arquivo da Universidade de Coimbra. II (1976) 220 e 222.

${ }^{23}$ New Catholic Encyclopedia, cit., p. 284-287. 
inquiridores, um distribuidor, um contador, um solicitador da justiça, um aljubeiro, um porteiro e alguns arciprestes (igualmente designados vigários forâneos) $)^{24}$.

A proliferação de regimentos destes tribunais no decurso da Época Moderna é a prova cabal de que se passou a conferir cada vez mais importância à gestão das dioceses e ao esforço de racionalização dos seus processos administrativos. A tendência insere-se ainda no contexto do reforço do poder do bispo, no que diz respeito à consolidação das suas competências jurisdicionais, ao controlo mais eficaz sobre a administração e justiça diocesanas e ao alargamento da sua capacidade de acção e governo sobre as populações e sobre a vida religiosa dos bispados. Através destes códigos normativos foram redefinidas as funções dos órgãos e dos oficiais da administração episcopal, quer ao nível do funcionamento dos aparelhos centrais do governo diocesano, quer em relação à oficialidade periférica e ao desenvolvimento de dispositivos de controlo do território ${ }^{25}$.

O primeiro regimento que se conhece de um Auditório é o que foi mandado compilar em Évora, em 1535, pelo arcebispo D. Afonso, o qual circulou de forma manuscrita e veio a ser alvo de adições durante o governo do arcebispo D. João de Melo, em 1565. Já depois de Trento, praticamente todas as dioceses fizeram publicar os seus regimentos de auditórios sob forma impressa, geralmente incorporados nas edições das constituições sinodais, o que acontecerá também no espaço ultramarino. São disso exemplo o do Porto (1585), Évora (1598, acrescentado em 1599), Leiria (1598), Viseu (1617), Portalegre (1632), Elvas (1635), Algarve (1674), Lamego (1683), Baía (1720) e Goa (1810) ${ }^{26}$. O de Coimbra, mandado elaborar pelo bispo D. Afonso de Castelo Branco em 1591, foi publicado em 1592 conjuntamente com as Constituições Sinodais, tendo sido reimpresso em

${ }^{24}$ PAIVA, José Pedro - Dioceses..., cit., p.187-199; Regimento dos officiaes do Auditório Ecclesiástico do bispado de Coimbra (...). Coimbra: Real Colégio das Artes, 1728 ( $1^{\text {a }}$ edição em 1592).

${ }^{25}$ PAIVA, José Pedro - Dioceses..., cit., p. 187-199; PALOMO, Federico - A Contra-Reforma ..., cit., p. 32-42; PALOMO, Federico - La autoridad de los prelados tridentinos y la sociedad moderna. El gobierno de don Teotónio de Braganza en el arzobispado de Évora (1578-1602). Hispania Sacra. 47 (1995) 587-624.

${ }^{26}$ PAIVA, José Pedro - Dioceses..., cit., p. 187-199. 
1728 no Real Colégio das Artes $^{27}$. Outros porém, como o do Funchal (1589), foram impressos anos depois da publicação das Constituições Sinodais. A mesma linha parece ter seguido o Regimento da Guarda (não constante das constituições e desaparecido), o de Lisboa (em cujas constituições de 1646 não aparece) e o de Braga (1699) que também foi usado na diocese de Miranda ${ }^{28}$.

Além de definirem a composição dos tribunais, estes regimentos fixavam o perfil, a esfera de acção e competências requeridas aos seus vários agentes. Determinava ainda a praxis a observar no governo quotidiano, nomeadamente os dias, locais, horas e modo de funcionamento das sessões de audiências, com o estabelecimento do tempo preciso em que cada oficial deveria intervir no decurso das mesmas, penas a cominar aos oficiais faltosos, modo de proceder nas causas sumárias ou condenações de pequenas quantias em dinheiro, actuação em relação às suspeições contra os oficiais do Auditório, embargos e dilações às causas pendentes.

O modelo organizativo que funcionava nos arcebispados de Évora, Lisboa e Braga diferia daquele que vigorava nas restantes dioceses. Enquanto instâncias de recurso, a actividade que desenvolviam era muito mais intensa do que numa simples diocese, pelo que a máquina burocrática existente era muito mais pesada.

No Auditório de Coimbra realizar-se-iam sessões frequentes, pelos menos duas por semana (Terças-feiras e Sábados), às quais todos os oficiais deveriam assistir, sob pena de pagarem pela primeira falta cem réis, pela segunda o dobro e, caso fossem contumazes, serem imediatamente suspensos ${ }^{29}$. Se as sessões calhassem num dia de feriado, deveriam ser adiadas para o dia seguinte. $\mathrm{O}$ vigário-geral deveria fazer as audiências em casa pública

${ }^{27}$ Regimento (...) de Coimbra..., cit..

${ }^{28}$ PAIVA, José Pedro - Dioceses..., cit., p. 187-199; PAIVA, José Pedro-The Portuguese secular clergy in the sixteenth century and seventeenth centuries in ANDOR, Eszter e TOTH, István Gyorgy - Frontiers of Faith. Religious Exchange and the Constitution of Religious Identities, 1400-1750. Budapest: Central European University, European Science Foundation, 2001, p. $157-166$.

${ }^{29}$ Regimento (...) de Coimbra..., cit., fl.19. Por seu turno, a Mesa do Despacho deveria reunir às Segundas e Sextas ou em dias que fossem vésperas de sessões de audiências. Os feitos apenas poderiam ser despachados em Mesa na presença do provisor, vigário-geral e desembargadores, ver Regimento (...) de Coimbra ..., cit., fl. 10v-14v. 
do Auditório e nunca em sua casa. A preparação das sessões tinha uma dimensão sensivelmente ritualizada, pois de acordo com o que o Regimento ordenava, meirinho, escrivães, inquiridores, distribuidor e porteiro deveriam acompanhar o vigário-geral desde a sua casa até à audiência e daí no retorno até casa. As penas para quem não cumprisse esta determinação eram as mesmas que se aplicavam a quem faltava às sessões ${ }^{30}$.

Às Sextas-feiras dever-se-ia fazer uma audiência aos presos no aljube, na presença dos oficiais do Auditório e dos advogados dos presos. Os oficiais faltosos incorreriam nas mesmas penalizações estipuladas para as restantes sessões, e os advogados que não fossem pontuais perderiam a antiguidade na audiência, ficando ainda ao arbítrio do vigário-geral a eventual aplicação de penas pecuniárias. Caberia ao vigário-geral publicar os feitos que levasse despachados e os advogados pronunciar-se-iam segundo a sua antiguidade. No fim de cada audiência, o vigário-geral deveria ordenar ao porteiro que, em voz alta, perguntasse se alguém tinha algo mais a requerer.

A abertura de um procedimento judicial, que ocorreria apenas nos casos mais graves, iniciava-se com a formalização de denúncias da autoria de pelo menos duas pessoas, as quais poderiam ter origem em sede de devassa, isto é, advir das visitas pastorais, ou ocorrer por iniciativa de denunciantes que se deslocavam ao Auditório. Nas causas que não fossem sumárias ou de pequenas quantias, o vigário-geral deveria realizar audiência, salvo nas causas matrimoniais, beneficiais e criminais entre partes, as quais seriam tratadas por desembargo na Mesa do Despacho, isto é, na Câmara Eclesiástica $^{31}$. Formalizada a denúncia, o denunciante era submetido a um interrogatório relativamente intenso. $\mathrm{Na}$ sessão de audiência o vigáriogeral ouviria as testemunhas, os advogados e o promotor. Ao contrário do que acontecia por exemplo no Santo Ofício, onde era vedada ao réu a possibilidade de tomar conhecimento das acusações que pendiam contra si, no Auditório o arguido era informado dos artigos incriminatórios, com referência aos factos precisos de que era acusado, no sentido de os contender e desmentir até à segunda audiência. Caso tivesse alguma excepção que impedisse a contestação, deveria verbalmente alegá-la, dando-se dela

\footnotetext{
${ }^{30}$ Regimento (...) de Coimbra..., cit., fl.18v.

${ }^{31}$ Idem, fl. 6-6v.
} 
conhecimento ao procurador para a apresentar no tempo legalmente definido para interpor contraditas ${ }^{32}$.

Durante o julgamento do processo, caso o delito cometido fosse grave, houvesse presunção de que o réu fugiria, ou ele fosse reincidente, ordenar-seia de pronto a sua prisão. Nenhum indivíduo poderia ser posto em liberdade sem que tal ficasse registado pelos escrivães da câmara, do auditório e da visitação. Seguia-se a apresentação do libelo, o qual era passível de ser impugnado através de uma contestação. Sucederia, nestes casos, a dilação do processo. No sentido de a evitar e obstar a que os réus recorressem para outros tribunais, o Auditório exigia-lhes, no momento do requerimento, o depósito prévio nos seus cofres (arca) de um determinado quantitativo, geralmente avultado, destinado ao pagamento dos custos da dilação. Caso se provasse que os réus tinham razão ao desconfiarem de algum dos oficiais, o dinheiro depositado ser-lhes-ia devolvido. Sucedendo o inverso, perderiam esse quantitativo e acrescer-lhe-ia ainda o valor pecuniário da pena determinada na sentença. Se o suspeitante fosse pobre, a caução poderia ser moderada. Os juízes das suspeições deveriam despachá-las no termo máximo de 45 dias, sob pena de serem suspensos pelo bispo. Se sucedesse que a parte contrária no processo solicitasse ver as suspeições com o objectivo de as impugnar, a causa ficaria ordinária, isto é, sem prazo definido para o despacho final. Apenas não se actuava desta maneira nos casos de excomunhão, de falso procurador e outras excepções semelhantes, em relação às quais se aplicaria o estipulado no Direito Canónico em geral. Para que as suspeições fossem aceites, deveriam ser redigidas por um dos advogados do Auditório, e apresentadas por escrivão ou notário apostólico do mesmo Tribunal. Antes de se determinar a sentença, o réu seria presente à sala de audiências, onde lhe era dado a conhecer o teor das acusações que contra si pendiam, bem como o nome dos acusadores. Tinha, pois, o direito ao exercício do contraditório, podendo inclusivamente nomear outras testemunhas que abonassem o que afiançava. Se conseguisse provar a sua inocência, o processo seria arquivado. Ocorrendo o contrário, seria sentenciado. As sentenças definitivas não poderiam ser comutadas a não ser pelo bispo. Nos casos mais graves, nomeadamente os excomungados,

\footnotetext{
${ }^{32}$ Idem, ibidem.
} 
seria mesmo por vezes necessário obter bulas de absolvição, muito embora além do cumprimento da pena fosse determinante a remissão da alma. Relativamente aos sacrílegos que antes da sentença e depois de obter o perdão da parte ofendida, pretendessem absolvição da excomunhão, deveriam depositar "quantia em ouro ou prata suficiente para que bem valha a pena do sacrilégio" 33 .

No que diz respeito à relação com outras instâncias, o Regimento de Coimbra apenas continha disposições relativas ao tribunal da Inquisição, denunciando um intento de colaboração: "Por haver Inquisição não tomará o vigário-geral das coisas tocantes à Santa Fé Católica, salvo se pelos oficiais do Santo Oficio lhe for deferido. Porém, vindo-lhe alguma denúncia deverá remete-la ao Santo Ofício, e se as culpas forem tais que o denunciado mereça ser preso, o prenderá com o resguardo e diligências devidas, principalmente havendo o perigo em a tardança, e sendo preso logo será remetido com os autos ao Santo Ofício"34.

Os salários dos oficiais variavam de caso para caso mas, em regra, não eram fixos. Auferiam de acordo com a natureza e quantidade dos casos sobre os quais laboravam. Em regra, os valores encontravam-se definidos no Regimento do Auditório. Noutras situações, este código normativo remetia para o regimento dos tribunais seculares. O vigário-geral estava incumbido de assinar as sentenças apenas depois do respectivo escrivão lhe provar que todos os oficiais tinham sido remunerados. Os proventos eram, pelo menos em parte, gerados pelo próprio Tribunal, em razão das coimas e penas pecuniárias que aplicava ${ }^{35}$.

\section{A devassa geral ordenada por D. Miguel da Anunciação}

Corria o ano de 1741 quando o bispo de Coimbra, D. Miguel da Anunciação (1740-1779), ordenou que se tirasse devassa geral aos oficiais do

${ }^{33}$ Regimento (...) de Coimbra..., cit., fl.6-7v e 10v-14; SILVA, José António Gomes da - Tribunais..., cit., p. 303-305. Veja-se ainda NUNES, João Rocha-Crime e castigo..., cit., p. 177-213.

${ }^{34}$ Regimento (...) de Coimbra..., cit., fl. 5-6.

${ }^{35}$ Regimento (...) de Coimbra..., cit., fl. 16v-17v. 
Auditório Eclesiástico de Coimbra. O objectivo era muito claro, velar pela boa e recta administração da justiça. A devassa consistia na instauração de um conjunto de interrogatórios destinados a verificar se o Tribunal estava a funcionar correctamente e se os seus oficiais cumpriam as obrigações a que estavam sujeitos.

Várias poderão ter sido as razões que motivaram o prelado a desencadear esta inspecção. Em primeiro lugar, note-se, as devassas eram um instrumento legal destinado a apurar eventuais ilegalidades no seio dos tribunais e punir os seus mentores. Assim acontecia nos juízos seculares e na Inquisição, a qual tinha também mecanismos de fiscalização e vigilância interna. De resto, o próprio Regimento do Auditório conimbricense exigia que, em tempo de férias, o vigário-geral fizesse correição anual a todos os oficiais, no sentido de inquirir diligentemente se eles cumpriam e acatavam as disposições estipuladas. Tratava-se de interrogar as testemunhas que lhe parecessem mais apropriadas para apurar a verdade, "principalmente os que tem ou custumão ter negócios em nosso Auditório: e perguntara pelo menos trinta e as devassas que fezer comunicará comnosco para se lhes dar o despacho que for justiça" 36 .

Para perceber os motivos da devassa, dever-se-á ainda ter em consideração a longa sede vacante que antecedeu a nomeação de D. Miguel em 19 de Dezembro de 1740. É possível que a inexistência de bispo tenha contribuído para que alguns dos agentes do tribunal se tenham revelado menos zelosos no cumprimento das suas funções. Não admira, pois, que D. Miguel da Anunciação tenha procurado, logo no início do seu governo, expurgar o Tribunal de eventuais ilicitudes, debelando os comportamentos ignóbeis de alguns oficiais.

Por outro lado, e não excluindo a hipótese acima aventada, é possível que tenha chegado ao conhecimento do bispo, através de denúncias ou queixas, que alguns oficiais não cumpriam as suas funções ou que, na generalidade, o Auditório funcionava mal.

Por fim, refira-se que esta devassa se insere no contexto da acção e pensamento do próprio prelado, vinculado em termos gerais ao iluminismo

\footnotetext{
${ }^{36}$ Regimento (...) de Coimbra..., cit., fl. 5-6.
} 
católico $^{37}$. Procurando integrar na esfera da Igreja o racionalismo crítico que nascera no campo do pensamento filosófico, os partidários desta nova tendência, de que Bento XIV (1740-1758) foi um exemplo, procuraram renovar a vida religiosa através do debate crítico sobre os problemas de doutrina, de culto e de disciplina. O plano de instrução, exame e vigia do clero e a campanha de erradicação de hábitos religiosos populares eivados de ignorância assentavam na combinação de várias medidas, entre as quais estavam a pregação pessoal do bispo, as visitas pastorais, as missões e determinadas normativas, e onde o correcto funcionamento dos órgãos da justiça episcopal não poderia marcar passo ${ }^{38}$. D. Miguel da Anunciação teria disso consciência quando, logo no início do seu episcopado, ordenou devassa geral ao Auditório. Acresce que D. Miguel fora um dos mais fervorosos adeptos do movimento da jacobeia, corrente que na aurora de Setecentos iniciou o seu percurso no Colégio da Graça em Coimbra, preconizando uma reforma muito exigente das formas de piedade e do comportamento dos religiosos ${ }^{39}$.

A devassa levada a cabo no Juízo Eclesiástico de Coimbra, decorreu entre 20 de Março e 15 de Maio de 1741, e constou de um lote exaustivo de questões acerca da conduta dos oficiais da justiça. Através delas poder-

${ }^{37}$ PAIVA, José Pedro - Os Bispos..., cit., p. 75; 515.

${ }^{38}$ PAIVA, José Pedro - Os Bispos..., cit., p. 72, 75, 159-164 e 170. Neste âmbito foi também significativa a fundação de um seminário até então inexistente na diocese, o qual teve estatutos confirmados por breve do papa Bento XIV, de 18 de Dezembro de 1748. Esteve inicialmente localizado, em 1741, em casas da freguesia de S. João de Almedina e depois em casas na freguesia de S. Martinho do Bispo, ficando definitivamente instalado em edifício próprio, construído entre 1748 e 1765. BANDEIRA, Ana Maria; SILVA, Ana Margarida; MENDES, Marta Luísa - Mitra Episcopal de Coimbra: Descrição Arquivística e Inventário do Fundo Documental. Boletim do Arquivo da Universidade de Coimbra. XXIII e XXIV (2003-2007) 87-137.

${ }^{39}$ DIAS, José Sebastião da Silva - Correntes do sentimento religioso em Portugal (sécs. XVI a XVIII). Coimbra: Instituto de Estudos Filosóficos da Universidade de Coimbra, 1960; PAIVA, José Pedro - Os Bispos ..., cit., p. 165; SERRÃO, Joel (dir.) - Dicionário de História de Portugal. Porto: Livraria Figueirinhas, vol.III, 1992; p.354-355; SANCHIS, Antonio Mestre - Polémicas sobre el Jansenismo y la bula Unigenitus a principios del siglo XVIII. Estudis - Revista de Historia Moderna. 24 (1998) 281-292; SILVA, António Pereira da A questão do sigilismo em Portugal no século XVIII. História, religião e política nos reinados de D. João V e de D. José I. Braga: Tip. Editorial Franciscana, 1964, p.50.145; SOUZA, Evergton Sales - Jansenisme et reforme de l'Église dans l'empire portugais 1640 à 1790 . Paris: Centre Culturel Calouste Gulbenkian, 2004, p. 187-234. 
-se-á compreender mais facilmente não apenas qual o âmbito e a natureza das suas funções, como também, quais as matérias que preocupavam o antístite. As questões constantes do interrogatório, são várias, nomeadamente aquelas que se destinavam a apurar se os seus oficiais eram corruptíveis; se favoreciam ou prejudicavam algum réu a troco de dinheiro e favores; se cometiam excessos na cobrança do dinheiro pelo trabalho operado; se quebravam o segredo da justiça e se tinham tido trato desonesto com réus ou estavam amancebados ${ }^{40}$.

No que diz respeito às perguntas de carácter mais específico, pretendeu-se saber se o meirinho tinha preso alguém sem ordem expressa para isso, salvo em flagrante delito; se vendo alguém desrespeitando o degredo o tinha colocado em cativeiro; se ao encarcerar alguém usara injúrias físicas ou verbais; se levara os presos para o aljube, para outra prisão secular, ou os retivera em sua casa; se cobrara algo aos presos por se deslocarem a audiências ou penitências públicas; se libertou alguém antes do despacho formal do provisor ou vigário-geral. Relativamente ao inquiridor o objectivo era saber se ele tinha permitido a presença dos envolvidos num determinado processo, enquanto interrogava as testemunhas nomeadas. Sobre o distribuidor, os oficiais encarregues da devassa tinham o fito de perceber se distribuía correcta e equitativamente o serviço disponível por cada escrivão; se mostrava o livro de distribuição aos escrivães sem ordem do provisor ou vigário-geral, ou, ausentando-se, procurava deixá-lo a quem o vigário-geral nomeasse. Quanto ao inquiridor apurou-se se inquirira pessoas que não constavam do rol de nomeados pelas partes; se fizera perguntas não previstas nos artigos da sessão de inquirição; se assinara o livro de alguma inquirição não efectuada por si e se cobrara dinheiro por esse trabalho; se interrogara várias testemunhas ao mesmo tempo sobre o mesmo ou diferentes casos. A propósito do contador a inspecção indagou se efectuava as contas com desvelo; se procurava inteirar-se junto das partes relativamente ao dinheiro que os escrivães e advogados lhes cobravam; se cumpria a Lei do Reino, segundo a qual deveriam apenas contar 25 regras por página e trinta letras

${ }^{40}$ AUC - Caixas da Câmara Eclesiástica, Devassa geral para se saber do procedimento dos reverendos ministros da Mesa da Justiça Eclesiástica e dos mais oficiais da justiça, III/D, 1,6,2,19, 5, fl. 3-6v (doravante apenas AUC - Devassa Geral...). 
em cada regra. Do aljubeiro verificou-se se tinha deixado fugir algum preso por sua culpa; se alargara ou encurtara o tempo de prisão indevidamente; se soltara algum preso sem alvará de soltura; se consentira que os cúmplices de amancebamento contactassem com os presos; se comera ou bebera com presos ou aceitara deles oferendas; se vendera ou comprara algum bem pertencente aos encarcerados, ou os obrigara a trabalharem para si ou para a sua família; se consentira blasfémias, juramentos, jogos vários no aljube, ou permitira que os indivíduos em cativeiro se travassem de razões ${ }^{41}$.

Não ficavam por aqui as inquirições. Sobre os ministros pretendeu-se saber se eram assíduos na Mesa do Despacho e diligentes nos despachos dos feitos. O lote de questões sobre o promotor incidia sobre o seu empenho nas audiências em que estava presente; o esmero em tomar conhecimento de casos de clérigos que por má conduta escandalizavam os fiéis; o cuidado em certificar-se de que depois de apresentar os seus sumários, as causas tinham seguimento através da interrogação de testemunhas, realização de novas denúncias ou devassas; o primor na defesa da jurisdição episcopal e na supervisão dos outros oficiais relativamente ao cumprimento do Regimento. No que tocava aos comissários, indivíduos a quem era conferida a incumbência de ouvir testemunhas por impedimento do inquiridor, as perguntas destinavam-se a apurar se tinham tomado refeições em casa dos indivíduos envolvidos nos processos ou de seus familiares e amigos, e se inquiriam as testemunhas em locais inadequados. No referente aos advogados, interessava saber se permitiam treslados ou certidões de autos ou os enviavam para outros juízos sem ordem do provisor ou vigário-geral. Quanto aos escrivães, as inquirições destinavam-se a saber se eram diligentes na prossecução das causas; se faltavam ao respeito para com os réus; se passavam certidões ou enviavam documentos para outros juízos sem ordem do provisor ou vigário-geral; se retinham dinheiro indevido por tempo indeterminado sem o depositarem nos cofres do Tribunal; se tinham saído da cidade por período superior ao permitido (um dia), sem para isso estarem autorizados, e se tinham examinado testemunhas na ausência do juiz ou inquiridor. Seguia-se o interrogatório sobre o solicitador da justiça. Neste âmbito procurava-se saber se era empenhado em requerer inquirições e fazer correr

${ }^{41}$ AUC - Devassa Geral..., fl. 3-6v. 
os feitos da justiça, dos resíduos e, sobretudo, dos presos e dos prazos; se havia solicitado ou requerido algo a favor dos arguidos e contra a justiça; se tinha celebrado contrato ilegal com as partes e se recebera ilegalmente dos condenados parte da pena pecuniária aplicada pelo meirinho. Sobre os corredores das folhas a preocupação era apenas saber se levavam a cabo o seu trabalho com o esmero e dedicação necessários. Finalmente, o porteiro. As testemunhas foram intimadas a dizer se este oficial era falto em abrir as portas da casa do Auditório, em varrer e limpar as salas do edifício e assistir às audiências ${ }^{42}$.

Os interrogatórios das testemunhas notificadas por Teotónio Monteiro, solicitador da justiça, iniciaram-se em 20 de Março, na casa de António de Alvarenga Peixoto, desembargador da Mesa da Justiça Eclesiástica da cidade e bispado de Coimbra, juntamente com o notário apostólico. Foram interrogados 39 indivíduos, com idades compreendidas entre os 24 e os 74 anos de idade. Como se poderá visualizar através do gráfico $\mathrm{n}^{\circ} 1,54 \%$, ou seja, 21, eram funcionários do Auditório; 36\%, correspondentes a 14, não laboravam no Tribunal e, finalmente, 4, ou seja, 10\% do total, não se sabe se exerciam funções no Tribunal episcopal, pois aparecem referenciados apenas como licenciados.

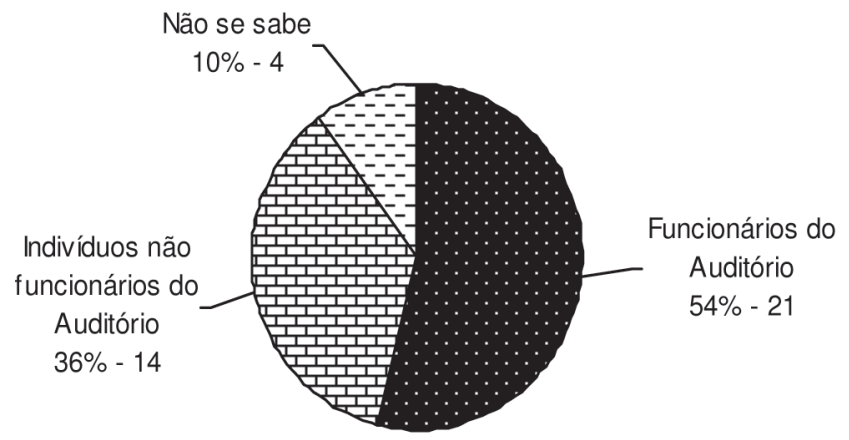

Gráfico 1 - Funções das testemunhas ouvidas

A inquirição de um maior número de oficiais do Juízo Eclesiástico, explica-se pelo facto de se tratar de pessoas que conheciam como ninguém a dinâmica interna do Tribunal. No lote destes sujeitos encontramos

${ }^{42}$ Idem. 
17 advogados, 2 solicitadores, 1 contador e um indivíduo nomeado como oficial da justiça, mas sem menção à função que exercia. Inquirir advogados revelava-se essencial. Além de poderem advogar noutros tribunais, tendo, portanto, uma visão mais alargada dos deveres e funções dos vários oficiais, lidavam de perto com os casos instruídos no Auditório, tendo, por isso, um conhecimento extenso sobre eventuais problemas relacionados com incumprimentos, ilegalidades ou negligências.

Nem todos os inquiridos eram, porém, funcionários do Tribunal. Entre estes encontram-se 9 clérigos, duas testemunhas que viviam da sua fazenda, um moleiro, um lavrador e um alfaiate.

Relativamente aos clérigos, eram aqueles que no seio das paróquias, ao exercerem a função de cura de almas, tinham um conhecimento profundo do quotidiano dos fiéis, podendo assim ter notícia de algo susceptível de ser denunciado. No que diz respeito aos leigos, eram pessoas que tinham estado envolvidas nas malhas do Auditório Eclesiástico.

A origem geográfica dos inquiridos revela que a grande maioria era residente na cidade sede do bispado, isto é, 34 , sendo os restantes 5 de fora de Coimbra, como se poderá ver pelo gráfico $\mathrm{n}^{\mathrm{o}} 2$.

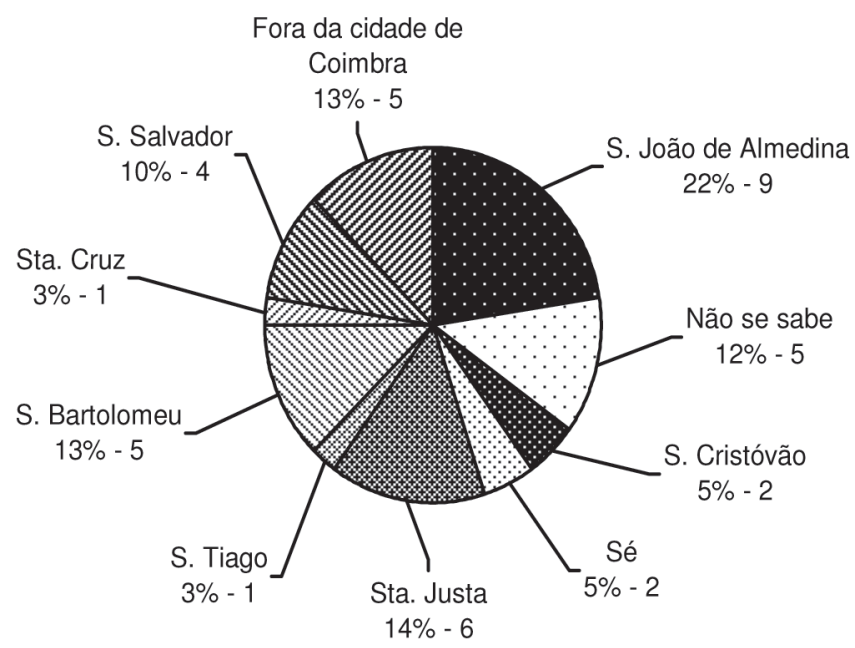

Gráfico 2 - Residência dos indivíduos inquiridos

Analisando agora os resultados da devassa, verifica-se que foram mais do dobro, isto é 28 , os indivíduos que testemunharam contra o funcionamento 
do Auditório e a conduta dos oficiais da justiça. Apenas 11 dos interrogados não denunciaram qualquer queixa.

Relativamente aos delatores, verificou-se que a esmagadora maioria depôs contra os escrivães do Auditório Eclesiástico. Como se poderá verificar no gráfico $\mathrm{n}^{\mathrm{o}} 3$, foram 24 os indivíduos que assim procederam. Entre os demais visados encontra-se o contador, com 5 acusações, os advogados com 4, os comissários com 2 e, finalmente, o meirinho e distribuidor com 1 acusação cada.

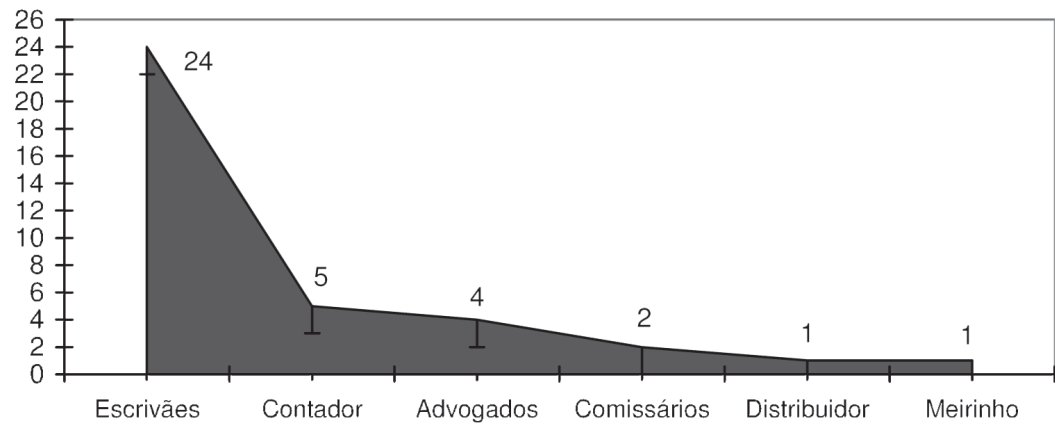

Gráfico 3 - Número de acusações por cada oficial do Auditório Eclesiástico

Atente-se então, em primeiro lugar, nos escrivães, oficiais sobre os quais recaiu o grosso das acusações. As queixas formuladas estavam maioritariamente relacionadas com questões de dinheiro. Tomando como exemplo os depoimentos da primeira testemunha inquirida, o licenciado Miguel Coelho de Sousa, este asseverou que os escrivães recebiam salário em duplicado por um mesmo serviço, isto é, cobravam dinheiro às partes e enviavam depois as contas ao contador para que, no fim da causa, fossem novamente remunerados pelo Tribunal. Além disto, segundo afirma, os escrivães José de Miranda e António Carvalho retinham dinheiros destinados ao pagamento de salários e aos cofres do Auditório:

"[...] em todas as contas que por este Juizo se tem tomado aos mesmos escrivães ficara sempre alcançado nellas o escrivam Jozeph de Miranda assim no dinheiro que pertence a arca como em sellarios que se 
contam aos procuradores nos quais tambem ouvio dizer publicamente ficara alcanssado o escrivão Antonio Carvalho [...]"43.

Esta questão dos salários foi amplamente denunciada pela generalidade dos advogados, os quais se sentiam lesados. Isso mesmo referiu Domingos Álvares Carneiro, procurador do Auditório, revelando que era público e notório entre os advogados que José de Miranda era remisso em:

“[...] pagar os salários a advogados e comissários que se contavam nos autos ficando com elles na mam" ${ }^{44}$.

Este escrivão foi recorrentemente acusado, uma vez que devia dinheiro a grande parte dos advogados. Além disso, retinha o dinheiro que era destinado à arca do Tribunal, sobretudo as receitas das condenações. Apenas para dar um exemplo, tinha em seu poder mais de 18 mil réis que, por sentença, um réu foi obrigado a pagar aos administradores de uma capela da freguesia de Santa Justa. Mas, não só. Era usual enviar caminheiros para estabelecer contactos com determinados indivíduos envolvidos nas malhas da justiça, sem encaminhar essas despesas para o contador, para por esta via ele próprio pudesse cobrar o dinheiro que lhe aprouvesse ${ }^{45}$.

Todavia, os depoimentos contra este escrivão ultrapassaram as questões de dinheiro. Além de não enviar aos advogados as causas com prontidão e diligência, retendo-as em seu poder durante mais de seis meses, de acordo com Domingos da Costa Montanha, advogado de 71 anos de idade, costumava:

"[...] agastar-ce munto com as partes quando a sua caza vam fallar-lhe nos seos negócios [...]"46.

${ }^{43}$ AUC - Devassa Geral ..., fl. 7v.

${ }^{44}$ Idem, fl. $13 \mathrm{v}-14$.

${ }^{45}$ Idem, fl. 12-12v. Testemunhos de casos idênticos poder-se-ão encontrar nos fólios $27-28 ; 29-30 \mathrm{v} ; 30 \mathrm{v}-32$.

${ }^{46} \mathrm{AUC}-$ Devassa Geral ..., fl. 11-11v e 22-23v. 
Esta era uma prática que José da Silva também evidenciava. De resto, estes dois escrivães, segundo o depoimento do advogado Hilário de Carvalho, tratavam mal os réus, sendo rudes, grosseiros e descomedidos. Neste particular, José de Miranda teria agido da seguinte forma para com a testemunha:

“[...] lhe pedia dinheiros por varias vezes [...] e quando lho não dava com elle se irritava, e que pagou-lhe tudo quanto lhe pedio pera expedir a sua appelaçam, e ha muntos tempos o tem feito vir a esta cidade infinitas vezes $[\ldots]$ pera lhe concluir o treslado" 47 .

Agiu ainda mais barbaramente com Lázaro Pereira Barreto. Indo a sua casa para que ele exarasse um despacho, de acordo com o que determinara o provisor que servia de vigário-geral, o escrivão recusou-se a fazê-lo. Ao que parece, José de Miranda solicitara-lhe 4 ou 5 moedas de ouro a troco do trabalho, o que o requerente recusou, dizendo que iria formular queixa acerca do sucedido. Foi então que o escrivão o tornou a chamar para a sua sala e o injuriou:

"[...] hera hum insolente e hum dezavergonhado e outras mais palavras injeriozas de que nam tem lembrança e que lhe nam queria tornar a dar a dita petissam [...] a cujo tempo se levantara tambem contra elle testemunha na dita salla o filho mais velho do dito escrivam chamado segunda sua lembrança Joseph Antonio descompondo-o e metendo a mam pera a algebeyra como querendo desta sorte atemorar e com tal excesso que as mesmas filhas e mulher vieram a dita salla acomoda-los o que vendo elle testemunha se viera pella escada abayxo $[\ldots]^{\prime 48}$.

${ }^{47}$ AUC - Devassa Geral..., fl. 15v-16v. Um testemunho de caso idêntico poder-se-á encontrar em fl. 33-34.

${ }^{48}$ AUC - Devassa Geral..., fl. 36-36v e 38v-39. 
Passando à análise das acusações que recaíram sobre o contador, cumpre dizer que elas estão, de certa forma, relacionadas com as que visaram os escrivães no tocante a questões de dinheiro. Ao lavrarem rol das despesas de determinado feito, não procuravam saber junto dos indivíduos envolvidos se estes tinham já pago aos escrivães e advogados. Desta forma, o que sucedia era que as partes envolvidas acabavam por pagar em duplicado ${ }^{49}$. Foi precisamente esta a acusação que mais pendeu sobre os advogados, acusados de ganância, não apenas por cobrarem às partes mais dinheiro do que o devido, mas também por maquinarem situações que lhes possibilitavam auferir o dobro ${ }^{50}$.

Ao que parece, os comissários fariam o mesmo. João da Costa, beneficiado na igreja de Santa Justa, atestou ter conhecimento de que o comissário José Tavares Rochedo, vigário de Figueira de Lorvão, cobrara 200 réis apenas por uma informação que o padre Manuel da Paz lhe requereu que fizesse chegar ao Auditório ${ }^{51}$.

Com apenas uma acusação, o inquiridor e o meirinho. O primeiro foi denunciado por se ter ausentado algumas vezes, deixando o livro da distribuição ao promotor. O segundo, de acordo com o relato do solicitador António Simões Pereira, tinha uma mulher por sua conta, em Montemor-o-Velho, com quem mantinha uma relação de concubinato ${ }^{52}$.

Depois de interrogadas as testemunhas, e certamente devido ao facto do resultado dos interrogatórios revelar ilegalidades e desvios financeiros, os inquiridores ordenaram, em 15 de Março de 1741, que as contas relativas a pagamentos efectuados aos escrivães durante a década imediatamente anterior, fossem tresladadas, com o objectivo de serem analisadas e apensas aos autos da devassa.

Dois meses depois, em 15 de Maio, os autos de devassa foram publicados no cartório da Câmara Eclesiástica. No dia seguinte, saiu a sentença. $\mathrm{O}$ resultado era claro no tocante à tomada de medidas contra os abusos detectados. No entanto, apenas dois indivíduos foram condenados:

\footnotetext{
${ }^{49}$ Idem, fl. $7 \mathrm{v}, 14 \mathrm{v}-15 \mathrm{v}, 17-18,24-25$ e $26-26 \mathrm{v}$.

${ }^{50}$ Idem, fl. $11-11 \mathrm{v}$ e $19-19 \mathrm{v}$.

${ }^{51}$ Idem, fl. $27-28$ e $35-35 \mathrm{v}$.

${ }^{52}$ Idem, fl. $9 \mathrm{v}-10$ e $17-18$.
} 
"[...] obrigue esta devassa pelo que rezulta das testemunhas della a José de Miranda escrivam deste juízo ser prezo e suspenso, e obrigue tambem a que se livre como seguro, e suspenso Brás Nugueira Guimarães, escrivam das armas, notefique-se este para preparar seu Livramento e aquelle se de a rol ao meirinho"53.

Termina esta devassa com um registo do seu custo, o qual, de acordo com a legislação do Tribunal e na linha do que acontecia com os demais processos instaurados, foi suportado pelos condenados. O notário recebeu 2054 réis; o solicitador da justiça 660 réis pelo trabalho de avisar 33 testemunhas, e ao desembargador foram pagos 780 réis. O total das despesas contabilizou 3494 réis que, repartidos pelos dois réus, originou o pagamento de 1747 réis a cada um. A esta cifra acresciam depois as despesas do libelo, traslado da culpa e outros articulados. Apenas nos casos em que a justiça fosse parte acusadora e se provasse a inculpabilidade dos réus, o Auditório arcaria com as custas dos processos, o que aconteceria com esta inspecção caso não revelasse irregularidades. Não limitaria isso o zelo episcopal em apurar, por esta via, anomalias no funcionamento do Tribunal? Não se sabe, mas é provável que os antístites desencadeassem inspecções deste tipo apenas quando tinham presunção da existência de irregularidades no seio do Juízo Eclesiástico. Deve ter sido essa a razão que moveu D. Miguel da Anunciação a ordenar esta devassa, pois dos testemunhos se percebe que as deformidades detectadas eram públicas.

\section{Considerações finais}

Do exposto relativamente ao número de oficiais que laboravam no Auditório Eclesiástico e às funções que lhe estavam consignadas, parece poder concluir-se que o Tribunal Episcopal era um aparelho judicial fortemente burocratizado e relativamente organizado. Porém, como qualquer instituição, também os organismos da justiça episcopal podiam viver situações de injustiça e corrupção. Por conseguinte, havia mecanismos

\footnotetext{
${ }^{53}$ Idem, fl. não numerado.
} 
internos como as devassas gerais, destinados a inspeccionar o funcionamento do Tribunal com o objectivo de expurgar as práticas que obstavam ao cumprimento integral da aplicação da justiça e disciplinar os seus obreiros. A devassa ordenada por D. Miguel da Anunciação denotou isso mesmo. O Auditório de Coimbra continha no seu seio indivíduos pouco atreitos ao recto exercício das suas funções e que davam azo a escândalos, motivados por situações de abuso de poder relacionadas com questões de dinheiro. Se a situação eventualmente mais folgada em termos de vigilância resultante da conjuntura de sede vacante, patente no período imediatamente anterior ao múnus de D. Miguel da Anunciação, interferiu ou impulsionou, quer o comportamento réprobo de alguns oficiais, quer a decisão da realização da devassa, não se poderá assegurar de forma peremptória. Assim como não se poderá afiançar que tenham sido exclusivamente as matrizes jacobeias do pensamento e acção do antístite conimbricense a ditar a realização deste procedimento judicial. Este era, na verdade, um mecanismo legal previsto, como acontecia com outros tribunais do período Moderno, e em relação ao qual é possível conjecturar que o facto de ter sido posto em prática resultou, não apenas de uma, mas das várias hipóteses apontadas. O problema está em perceber o que se passou depois da sentença, pois a devassa nada mais informa acerca dos indivíduos condenados e do funcionamento do Tribunal, o que seria necessário para apurar não apenas o impacto real como também a funcionalidade deste tipo de inspecções. Além de procurarem suprimir as deficiências no âmbito organizativo e comportamental, estes dispositivos prestavam-se à definição do limiar de irregularidade suportável; restauravam a imagem do tribunal com a abertura de um processo de denúncias que ultrapassava a inquirição dos seus próprios agentes; e funcionavam como um instrumento de reafirmação do poder do antístite sobre os órgãos e agentes a ele subordinados ${ }^{54}$.

${ }^{54}$ De resto, como advoga Francisco Bethencourt em relação às visitas inquisitoriais de inspecção, é muito difícil determinar a eficácia destes mecanismos de vigilância e disciplinamento. Neste âmbito, o autor apresenta o caso de João Delgado Figueira, inquisidor do Tribunal goense acusado de mais de cem infracções, em relação ao qual não foram tomadas medidas disciplinares radicais, vindo o mesmo, de seguida, a gozar de uma carreira brilhante. BETHENCOURT, Francisco - História das Inquisições. Portugal, Espanha e Itália. Lisboa: Temas e Debates, 1996, p. 168-193. 
Além de sugerir algumas respostas, ressaltam deste estudo muitas questões. Que tipo de delitos eram mais usuais? Quais as sentenças previstas e que modelo foi mais bastamente aplicado? Verificava-se o seu cumprimento? De que dispositivos possuía o Tribunal para obrigar os réus a cumpri-las? As máquinas administrativas, as competências e qualidades dos vários oficiais, os modos de procedimento, as hierarquias internas de governo e funções, os circuitos de comunicação vertical interna da informação, eram semelhantes em todas as dioceses do Reino? Quais os limites de acção dos juízos eclesiástico, inquisitorial e régio e como conjugavam o exercício das suas influências? Em que sentido influenciavam a vida diocesana? E no que toca às relações entre os tribunais diocesanos e os de outras instâncias, qual a intensidade da colaboração e partilha de informação? Foram os auditórios sempre zelosos do cumprimento cabal da justiça? Eram estes organismos trampolim de carreiras? Tiveram impacto efectivo e de relevo no moldar dos comportamentos da cristandade católica? 